\title{
CHILD LABOR ISSUE AS DEPICTED IN ELIZABETH BARRET-BROWNING'S POEM THE CRY OF THE CHILDREN
}

\author{
Okki Irviana Nindi Astuti
}

\begin{abstract}
INTISARI
The Cry of the Children adalah sebuah puisi karya Elizabeth Barret-Browning yang diterbitkan pada tahun 1842. Dalam puisi tersebut, Elizabeth mengutarakan penolakannya terhadap penggunaan anak-anak sebagai tenaga kerja di pabrik-pabrik dan di pertambangan pada era Industri Revolusi. Buruknya kondisi para buruh anak-anak dari keluarga miskin di Inggris, baik fisik maupun psikologis, juga digambarkan dalam The Cry of the Children. Elizabeth menggunakan banyak diksi yang mampu menggambarkan secara jelas akan adanya isu buruh anak-anak selama Revolusi Industri di Inggris dan kesusahan yang harus mereka tanggung.
\end{abstract}

Kata kunci: buruh anak-anak, kemiskinan, Revolusi Industri, kesusahan.

\begin{abstract}
The Cry of the Children is a poem by Elizabeth Barret-Browning which was published in 1842. Through this poem, Elizabeth shows her objection to child labor in factories and mines in England. The bad conditions of those poor child labors, both physic and mental damages, are also demonstrated in The Cry of the Children. Elizabeth uses the right dictions which can show that child labor issue happened in England during the Industrial revolution and also the miserable life the poor children had to endure.
\end{abstract}

Keywords: child labor, poverty, Industrial Revolution, hardship.

\section{INTRODUCTION}

Industrial Revolution was a period in which fundamental changes occurred in agriculture, textile and metal manufacture, transportation, economic policies and the social structure in England. This started in 1760 and continued gradually. In the early $18^{\text {th }}$ century until $19^{\text {th }}$ century, the Industrial revolution was really exploding (http://yale.edu/ynhti/ curriculum/units/1981/2/81.02.06.x.html). It brought many impacts, both positive and negative. The positive impacts were; the national income increase, people from the lower and middle class, who had the proper education, could get jobs and earn more money, the city developed, and many more. On the other hand, the negative impacts of Industrial Revolution were poverty, pollution, urbanization, population increase, and child labor.

The existence of child labor appeared during the Industrial Revolution due to several reasons. One of them was that many people from the villages went to the cities to seek for jobs. They lived in slum areas near the factories or mines because living cost and rent were expensive there. Besides, those poor working class people also had a difficult time in fulfilling their daily needs. Therefore, in an attempt to ease the burden of life, parents asked their children to earn money. Another reason was that factory or coal mining owners wanted a high profit. If they hired the skilled 
workers, they had to pay them a high wage which could reduce their profit. As a result, they hired children since they could be paid cheaply. The children were required to sweep factory chimneys, to crawl in the pits, to scramble under machinery, to retrieve cotton bobbins, and many jobs that adults could not do (http://www.hiddenlives.org.uk/articles/ poverty.html).

One of many poets who lived during the Industrial Revolution was Elizabeth BarretBrowning. She wrote many poems conveying her hatred of slavery and child labor. One of them is The Cry of the Children. This poem has a sad tone. It contains of 13 stanzas and 160 lines. The rhyme of The Cry of the Children is irregular which is similiar with many of Elizabeth's poems. Unlike the rhyme scheme of sonnets which is regular and well ordered, the irregularity of this poem does not decrease the emotional feeling that Elizabeth was trying to build. The words used in this poem are easy to understand but they still show her strong feelings against child labor.

The objectives of this study are to (a) reveal Elizabeth Barret-Browning's point of view of child labor conveyed in The Cry of the Children, (b) analyze child labor issues portrayed, and (c) see whether the portrayal of child labor in The Cry of the Children represents child labor issues in England during the Industrial Revolution.

In accordance with the discussion above, this article focuses on the children's conditions. The conditions of the children are approached from two aspects: (a) industrial revolution, (b) child labor, and (c) the portrayal of child labor issue in The Cry of the Children. These two aspects are described in the following parts.

\section{INDUSTRIAL REVOLUTION}

From the eighteenth to the early nineteenth century, Great Britain faced a big revolution known as the Industrial Revolution. The
British economic system shifted from agriculture to trade and industry. There was a rapid expansion of trade and new markets, both in domestic areas and abroad. This change created a demand for increased productions.

The Industrial Revolution is a development of the economic condition started by some fundamental inventions and technological innovations. Those inventions and innovations were created by some educated and skillful men, such as Watt, Wedgwood, and Arkwright. Surprisingly, they came from the lower middle class. At that time, the lower and middle class society emerged as a business community. "With some education, a little capital, occasionally an influential relative, the expanding world offered them endless opportunity "(Plumb, 1959: 78). This means that the Industrial Revolution brought positive impact for the lower and middle class people who had sufficient education and technical background, and the spirit to survive. Without the expansion of the lower middle class, represented by Watt and Arkwright, the Industrial Revolution could not have happened since there had been no opportunities provided.

The most remarkable developments during the Industrial Revolution were in technology, transportation, and industrial organization system. Dr J.H. Plumb stated that in textiles, Arkwright's water frame (1769), Hargreaves's jenny (1770), and Crompton's mule (1779) revolutionized the production of yarn and brought to the weaver a golden age. A water frame is a tool used to spin cottons moved by water power, while jenny is an early multiple-spindle machine for spinning cotton or wool. Mule is a machine for simultaneously drawing and twisting fiber into yarn or thread and winding it into cops. Those inventions increased the capacity of textile production.

Abraham Darby, Cranages, Smeaton, and Cort's invention in reverberating, puddling, and rolling process made the production of cast iron rapid and cheap. In 1769, 
James Watt invented the steam engine which later made many factories driven by machines. Long before the invention of steam engine, the machinery was powered by horses or water.

The development in transportation resulted in the turnpike road, a canal and waterway, and a railway network. These developments made the trade and commercial activities closer and integrated. The canal was built in the late $18^{\text {th }}$ century to link the major manufacturing centers in the Midland and in the North with seaports and with London. Meanwhile, the railway system became important for the industry since it was used to support the movement of coal which was an important source of fuel. Then, the growing of country banks marked the development in industrial organization system. The production of silver and copper coinage and guinea notes made the industrial enterprise easier.

As there were changes in industries, the social structure also changed. The society became dynamic with these changes and problems also appeared. The increase of population, poverty, and mass urbanization characterized the reign of Queen Victoria. The Industrial Revolution led to the increase of population in England. After 1740, the population in Great Britain grew rapidly due to the decline in death rate.

The Industrial Revolution stimulated the building of many new factories, mostly in the big cities, such as London and Manchester. The existence of the factories created new job opportunities which then attracted people who lived in small villages to move to the cities in search of jobs.

\section{CHILD LABOR}

After 1740, there was an increase in population in England. There were many new born babies. For rich families, their newly born babies might have been a pleasure, but for the poor, it could be another burden. The living cost was very high and they had to feed another child in the family. Working class families could not earn much money since they were uneducated and unskilled.

One of the solutions to this bad condition was to force the children to work in a factory to ease the family's burden. Before the industrialization era, children had worked at home to help their parents. Those who lived on farms had to care for cattles, sheep, or milked the cows. During the industrialization era, children were forced to work in mines, mills, and other factories in a bad condition.

Besides poverty, the use of child labor was also triggered by the demand from factories. The invention of steam machine made factories run the production process on machinery system which resulted in the reduction of skilled labors. Then, many factory owners turned to unskilled labor and children as a replacement for skilled labor. They could also be paid cheaply to increase profit. "The Industrial Revolution created a great new demand for child labor in the textile factories. Often the children could find work, at exceedingly low wages, when the father could find none" (Cole, 1966).

\section{THE PORTRAYAL OF CHILD LABOR ISSUE IN THE CRY OF THE CHILDREN}

\begin{abstract}
Stanza 1
Do ye hear the children weeping, $\mathrm{O}$ my brothers, /Ere the sorrow comes with years?/ They are leaning their young heads against their mothers - /And that cannot stop their tears./The young lambs are bleating in the meadows; / The young birds are chirping in the nest;/The young fawns are playing with the shadows;/The young flowers are blowing toward the west-/But the young, young children, $\mathrm{O}$ my brothers, /They are weeping bitterly!/They are weeping in the playtime of the others,/In the country of the free.
\end{abstract}

In the first stanza, Elizabeth doesn't state the issue of child labor directly. She only describes that there are children crying in sorrow but the cause of the cry is not found yet. 
She begins the poem by delivering a question to "my brothers" which can be interpreted as the English society, members of Parliament, and factory or mine owners (http://courses. wcupa.edu/fletcher/britlitweb/ecummingsa. $\underline{\mathrm{htm}})$. The part where the children lean their heads against their mothers means they are seeking help from their mothers, but they cannot get the help.

Elizabeth provides metaphors to strengthen the sad condition of the children. She contrasts the sadness of the children in England to the happiness of the young lambs, birds, fawns, and flowers. Those young animals can be happy in the places where they belong to, but the children who live in England, a country which respects the freedom of self, cannot get the happiness in life.

\section{Stanza 2}

Do you question the young children in their sorrow, Why their tears are falling so? - The old man may weep for his to-morrow/ Which is lost in Long Ago - /The old tree is leafless in the forest - The old year is ending in the frost - The old wound, if stricken, is the sorest —/The old hope is hardest to be lost:/But the young, young children, $\mathrm{O}$ my brothers,/Do you ask them why they stand/Weeping sore before the bosoms of their mothers,/In our happy Fatherland?

The second stanza is similar to the first one, in the form of its arrangement. It begins with questions, followed by metaphors, and a satire to England. Elizabeth delivers a question to the English society, members of Parliament, and factory or mine owners why they doubt the fact that there are sad children in their country.

Then, Elizabeth provides metaphors which compare the sadness of the crying children to the sadness of old tree, old year, and old wound. These three old objects represent the natural condition of something which is close to death: the old tree refers to the old people who are not as energetic as youngsters, the frost represents sadness, and old wound represents the sensation of pain. However, they demonstrate an unnatural condition of the children. They had undergone misery at such a young age when actually they should have not. Elizabeth also describes that the children have already lost their hope and eagerness to live: The old hope is hardest to be lost.

\begin{abstract}
Stanza 3
They look up with their pale and sunken faces,/And their looks are sad to see,/For the man's grief abhorrent, draws and presses/Down the cheeks of infancy —/"Your old earth", they say, "is very dreary";/"Our young feet", they say, "are very weak!/Few paces have we taken, yet are weary - /Our grave-rest is very far to seek!/Ask the old why they weep, and not the children,/For the outside earth is cold —-And we young ones stand without, in our bewildering,/And the graves are for the old!
\end{abstract}

In this stanza, Elizabeth still describes the gloomy condition of the children. Their sad conditions led the children to start thinking about death. In this stanza, Elizabeth also uses some adjectives to show how miserable the lives of the children are, such as pale, sunken faces, sad, weak, and weary. The use of those adjectives makes the condition of the children vivid to the readers.

The reason of the dissolute life of the children is included in line 4 . It says that the elderly can no longer endure their miserable lives, so they include the children to feel and do as what they do. The word 'earth' refers to the life during the Industrial Revolution which was so miserable for the poor families. They had to face the long hours work with low wages, high prices of daily needs, and starvation.

Elizabeth describes that the children recognize the most dangerous risk caused by their confusing and severe condition which is death. It is represented by the word "grave" in Our grave-rest is very far to seek. The children know that they are not supposed to die 
young which is represented by the words "far to seek".

\section{Stanza 4}

"True", say the young children, "it may happen/That we die before our time!/Little Alice died last year - the grave is shapen/Like a snowball, in the rime./We looked into the pit prepared to take her —-Was no room for any work in the close clay:

From the sleep wherein she lieth none will wake her,/Crying, 'Get up, little Alice! it is day'./If you listen by that grave, in sun and shower,/With your ear down, little/Alice never cries! - Could we see her face, be sure we should not know her,/For the smile has time for growing in her eyes - A And merry go her moments, lulled and stilled in the shroud, by the kirk-chime!/It is good when it happens", say the children,/"That we die before our time!"

In this stanza, Elizabeth provides the illustration of the risk of death faced by the children. Some fatal accidents happened. Those who worked in mines died because of explosion, while children who worked in textile factories sometimes fell asleep then fell into the machines (http://www.ehow.com/ list 7582952 child-working-conditions-industrial-revolution.html). Unfortunately, the children consider that dying at a young age is better than spending their lives working with coals or wheels in factories. This stanza also shows that at a very young age, the children are very pessimistic about life.

Elizabeth provides an illustration of the death of a child labor named Alice. She died in a small pit of a mine because her tender body could no longer support her mandatory long working hours. Unfortunately, that small pit functions as her grave also. However, the children imagine that in her death, Alice can find the truest happiness. She has the smile and joy of life which she did not experience before.

\section{Stanza 5}

Alas, the wretched children! they are seeking/Death in life; as best to have!/They are binding up their hearts away from breaking,/With a cerement from the grave./Go out, children, from the mine and from the city Sing out, children, as the little thrushes do Pluck you handfuls of the meadow-cowslips pretty —/Laugh aloud, to feel your fingers let them through!/But they answer, "Are your cowslips of the meadows/Like our weeds anear the mine?/Leave us quiet in the dark of the coalshadows,/From your pleasures fair and fine!

Stanza 5 portrays the pessimistic children. They are told of ways to be happy which is to flee from the mines and the city. Unfortunately, the children refuse them all and prefer to endure every pain and sadness until they die. Elizabeth describes that the children are binding their hearts away from breaking with a cerement from the grave. This line shows that the children have opted for dying early/ young.

In this stanza, Elizabeth inserts similes by using singing little thrushes, pretty meadow-cowslips intended for the children to express the happiness by singing like the little thrushes and to feel the joy brought by the meadow flowers. However, the children have already doubt that those things can give them happiness. They think that instead of giving pleasure and happiness, the cowslips will offer them sadness like the weeds do. This children's doubt show their pessimism.

\section{Stanza 6}

"For oh", say the children, "we are weary,/And we cannot run or leap - If we cared for any meadows, it were merely/To drop down in them and sleep./Our knees tremble sorely in the stooping - /We fall upon our faces, trying to go;/And, underneath our heavy eyelids drooping,/The reddest flower would look as pale as snow./For, all day, we drag our burden tiring,/ Through the coal-dark, underground -/Or, all day, we drive the wheels of iron/In the factories, round and round.

In this stanza, Elizabeth portrays the child labors are in the meadows to take a short rest. However, in the meadow, they do not 
enjoy themselves. At that time, child labors worked 12 up to 19 hours a day, 6 days a week and they only got 1 hour break. They worked from 5 a.m. until 10 p.m. This bad condition of work made the children exhausted. (http:// www.ehow.com/list 7582952 child-working-conditions-industrialrevolution.html)

The first line shows that the children are absolutely exhausted from the long working hours. However, they cannot "run" or "leap" which means that they cannot escape or quit from the condition they are facing in the mines. They work to help their families. If they quit their jobs, they have to face their angry parents.

The rest of stanza 6 describes what the children do in mines and factories. It is a proof of child labor during the Industrial Revolution. Lines 9 and 10, For, all day, we drag our burden tiring, Through the coal-dark, underground - mean that if the children work in the coal mines, they have to crawl through many pits or tunnels dragging the coals upward. The children are the best ones to do this because of the size of their bodies. They can crawl in the pits underground, unlike the adults. Meanwhile, if the children work in factories, such as in textile factories, their jobs are to drive the wheels to spin the cottons or wools round and round. This is shown in lines 11 and 12, Or, all day, we drive the wheels of iron In the factories, round and round. Another job for the children who work in factories is to sweep the chimneys so that the black fumes will not block the chimneys.

\section{Stanza 7}

"For, all day, the wheels are droning, turning — Their wind comes in our faces — / Till our hearts turn - our heads, with pulses burning,/And the walls turn in their places —-Turns the sky in the high window blank and reeling Turns the long light that droppeth down the wall - Turn the black flies that crawl along the ceiling - A All are turning, all the day, and we with all! - And all day, the iron wheels are droning; And sometimes we could pray,/'O ye wheels' (breaking out in a mad moaning),/'Stop! be silent for to-day!"

The portrayal of the bad condition of the children continues in this stanza. It also shows the effects of long Working hours on the children's physical condition. At the beginning, the children were forced to work 16 hours a day, then a new regulation was passed by the Parliament to protect the children. This was the Factory Act of 1832 which states that children 9 to 13 years old were allowed to work 8 hours a day, children 14 to 18 years old could not work more than 12 hours a day, while children under 9 were not allowed to work at all. Even though their working hours were reduced, it was still a burden for children to work for 8 or 12 hours a day. The long working hours can ruin their health, physical, and psychological state. In addition, this stanza portrays the bad condition of the children's workplaces. They worked for 12 to 16 hours a day with only 1 hour break without meals. The places where they worked at were hot, stuffy, poor lit, and overcrowded. (http:// eh.net/encyclopedia/article/tuttle.labor.child. britain)

In the first line, Elizabeth portrays the children working with the iron wheels all day. She repeats "all day" like in lines 9 and 11 in stanza 6 to emphasize the long hours during which the children have to work. The turning motion, the droning sounds, and the winds coming out from the spinning wheels make the children become dizzy. Working in the factories does not only give the children headache, but also make their sight blurry. This is described in lines 4 to 8 .

Sometimes, in the midst of their dizziness and unhealthy condition, the children paused and prayed. This is shown in line 10, And sometimes we could pray, which indicates that the children still have their religiosity and pray to God. They expect God to help them ease their sorrows, an expectation which once failed when they asked their mothers for help. 
The children beg the wheels to stop spinning. This is found in the last two lines of stanza VII: 'O ye wheels' (breaking out in a mad moaning), 'Stop! Be silent for to-day!'. The adverb "breaking out in a mad moaning" indicates that the wheels are making an incessant noise which irritates the children. They express their anger by commanding the wheels to stop spinning.

\begin{abstract}
Stanza 8
Ay! be silent! Let them hear each other breathing/For a moment, mouth to mouth - Let them touch each other's hands, in a fresh wreathing/Of their tender human youth!/Let them feel that this cold metallic motion/Is not all the life God fashions or reveals - Let them prove their inward souls against the notion/That they live in you, or under you, O wheels! —/Still, all day, the iron wheels go onward,/As if Fate in each were stark;/And the children's souls, which God is calling sunward,/Spin on blindly in the dark.
\end{abstract}

In the first line of this stanza, Elizabeth tries to command the wheels to stop spinning for a moment and let the children free from their sound, $A y$ ! Be silent!. She utters her command sharply so that the factory owners will probably hear her command and pay attention to her. Thus stopping the machines for a moment and letting the children have a break.

Then she writes Let them hear each other breathing for a moment, mouth to mouthwhich is an order to the factory owners to let the children take a rest and catch a breath. The children are pictured as breathing from the mouths which indicates that they are absolutely tired. Their small bodies, hearts, and minds are exhausted. Elizabeth also goes on to say that the children should be given happiness and freedom.

As a religious person, Elizabeth wants to shout out that the hiring of children in mines or factories is not what God wants. God does not want the human creatures to live in sad and gloomy conditions. He wants to see
His creatures happy, to respect and take care of each other and nature. Elizabeth wants to say to the children that to work every day in mines or factories is not their fate. The one who makes the children trapped in this sad condition is the humans themselves.

\begin{abstract}
Stanza 9
Now tell the poor young children, O my brothers,/That they look to Him and pray So the blessed One, who blesseth all the others,/Will bless them another day./They answer, "Who is God that He should hear us,/While the rushing of the iron wheels is stirred?/When we sob aloud, the human creatures near us/Pass by, hearing not, or answer not a word!/And we hear not (for the wheels in their resounding)/Strangers speaking at the door; Is it likely God, with angels singing round Him,/Hears our weeping any more?
\end{abstract}

In this stanza, Elizabeth portrays the children as unlucky and atheist. They are stated as unlucky since God has not helped them yet. Elizabeth also considers them as atheists since they are in doubt of God. They believe that God will never give His mercy and help. Elizabeth wants people to be aware that the condition of the children is very bad, both physically and spiritually.

Elizabeth then creates an irony in lines 3 and 4, So the blessed One, who blesseth all the others, Will bless them another day. Those lines show that while God bless other people for the day, He does not bless the sad and miserable children. This is a symbol of the social gap in England during the Industrial Revolution. When God blesses people with happiness refers to the middle class people who could enhance their economic lives and enjoy the better condition of life. They could get better education, unlike the children who are not blessed by God. They still live in a miserable condition with no one caring for them. However, Elizabeth's holy advice is refused by the children, They answer, "Who is God that He should hear us, While the rushing of the iron 
wheels is stirred?" The sentence Who is God that He should hear us shows the children's distrust of God's existence. Elizabeth makes it so in order to show how desperate the children are.

The children consider that God is apathetic, so are the people around them. This is written in the next two lines, When we sob aloud, the human creatures near us, Pass by, hearing not, or answer not a word!. Elizabeth describes that when the children are crying because of the sad condition they are facing everyday, people are deaf to their cries. They pretend not to notice and choose to pass by. They are only interested in running their business and making money.

In the last three lines of stanza 9, Elizabeth writes Strangers speaking at the door: Is it likely God, with angels singing round Him, Hears our weeping anymore? Through these lines, Elizabeth builds an atmosphere of doubt, especially to God. She describes that God is deaf because of the singing melody from the angels, so He cannot hear the children's prayers. This is to arouse other Christians' awareness to the reality that the children are suffering and no one is helping them. If God helps and blesses them (the Christians), then why does $\mathrm{He}$ not bless the children. She wants to show that even if God does not help the children Himself, He will help them through human's hands. Elizabeth says that people, especially the Englishmen should do something about the child labor issue.

\section{Stanza 10}

"Two words, indeed, of praying we remember;/And at midnight's hour of harm -

'Our Father', looking upward in the chamber,/We say softly for a charm./We know no other words, except 'Our Father',/And we think that, in some pause of angels' song,/God may pluck them with the silence sweet to gather,/And hold both within His right hand which is strong./'Our father!' If he heard us, He would surely/(For they call Him good and mild)/An- swer, smiling down the steep world very purely /'Come and rest with me, my child.'

In this stanza, Elizabeth communicates to her readers that the children sometimes pray to God, even though they are pictured as those who are lacking of faith in Him. She wants to reveal that even a person who distrusts his/ her God, but when he/she is facing a very big problem in life and cannot do anything to solve the problem, he/she will remember God. This is how Elizabeth portrays the children in stanza 10. They remember God in the midst of their anger and lack of faith.

Elizabeth creates an irony when she describes that the children only remember two words when saying their prayers. Children are supposed to be able to recite their prayers because their parents send them to Sunday school or some other places where they can learn about religion. The only two words they know as depicted in this stanza shows how they lack lesson on religion.

And at midnight's hour of harm - shows that the children can only do their prayers at midnight. This is the time when the children are at home after working hard in their workplaces. However, they still try to pray although they are exhausted because of the long working hours that they have to endure. This is shown by the word "... of harm" which refers to their weak physical and mental conditions.

In line 12, the children hope that God would say 'Come and rest with me, my child.' as the answer to their prayers. This represents that the children are wishing for death and uniting with God. This is the happiness that they are waiting for.

\section{Stanza 11}

"But, no!" say the children, weeping faster,"He is speechless as a stone;/And they tell us, of his image is the master/Who commands us to work on./"Go to!" say the children _ " "up in heaven,/Dark, wheel-like, turning clouds are all we find./Do not mock us: grief has 
made us unbelieving:/We look up for God; but tears have made us blind./Do you hear the children weeping and disprovlng,/O my brothers, what ye preach?/For God's possible is taught by his world's loving —_And the children doubt of each.

This stanza repeats the idea that the children do not have faith in God. If in the previous stanza the children hope that God will finally help them, in this stanza, the children deny their own hopes. Elizabeth portrays the children being doubtful of God because of the harsh life they have to lead.

In line 1, Elizabeth writes "But, no!' say the children, weeping faster. The children negate their own hope that God will help them. They are also described as "weeping faster" which indicates that they become sadder. They have come to a conclusion that God will never help them. This makes them even sadder and despise God which is demonstrated in line 2: "He is speechless as a stone". Elizabeth inserts a simile that God is speechless as a stone. Their unanswered prayers make the children consider God as a stone.

In lines 9 and 10, Elizabeth questions the "brothers" by saying Do you hear the children weeping and disproving, $O$ my brothers, what ye preach? She wants to know whether the "brothers", which refers to the English society and members of Parliament, can recognize this social problem or not. The problem is represented by the crying children. It gets worse when the children become pessimistic and lacking faith in God. The interrogative "what ye preach?" can be interpreted as "what have you done to the crying children?" Elizabeth tries to trigger the people's awareness to this social issue by interrogating them with such a question. She wants the English to ask themselves what they have done wrong which makes many poor children in England live in a sorrowful condition.

The last two lines of this stanza are more about Elizabeth's remorse why the children are doubtful of God since He will never destroy His creatures. In line 11, Elizabeth writes For God's possible is taught by his world's loving - to show how God loves human and His existence can only be felt through love and kindness. However, the children cannot feel God's love since their dreadful life has already made them insensible and numb. This is shown in the last line: And the children doubt of each. They doubt that they can get help and kindness from God, and they doubt that they can lead a better and happier life.

\section{Stanza 12}

And well may the children weep before you!/They are weary ere they run;/They have never seen the sunshine, nor the glory/Which is brighter than the sun./They know the grief of man, without its wisdom;/They sink in man's despair, without its calm;/Are slaves, without the liberty in Christdom;/Are martyrs, by the pang without the palm:/Are worn as if with age, yet unretrievingly/The harvest of its memories cannot reap;/Are orphans of the earthly love and heavenly —/Let them weep! let them weep!

In stanza 12, Elizabeth portrays again the crying children with their miserable conditions. She uses some simile to emphasize how sad the conditions are. Moreover, the parables help the readers to imagine and to feel their misery.

Elizabeth's portrayal of how bad the condition of the child labors continues from lines 3 until 11. She describes that the children cannot taste the glory of life which is promised by God. They live miserably and nothing can cherish them. They are made slaves by many factory and mine owners. They are like martyrs who suffer from long working hours, but they do not get any beneficial result from it. As the result of all their sorrowful lives, their appearance looks older and forlorn than their actual ages.

In line 10, Elizabeth writes Are orphans of the earthly love and heavenly - to dramatize the dreadful condition. The children are said to be orphans because they do not get 
love from their parents which is represented by the phrase "the earthly love". They also do not have the love from God which is shown by the word "heavenly". Their parents do not take care of them well, instead they are busy making money to earn a living because of poverty. In addition, God is also said to be ignorant of their problems.

\begin{abstract}
Stanza 13
They look up with their pale and sunken faces,/And their look is dread to see./For they mind you of their angels in high places,/With eyes turned on Deity./"How long", they say, "how long, O cruel nation,/Will you stand, to move the world on a child's heart —-/Stifle down with a mailed heel its palpitation,/And tread onward to your throne amid the mart!/Our blood splashes upward, O gold-heaper,/And your purple shows your path!/But the child's sob in the silence curses deeper/Than the strong man in his wrath".
\end{abstract}

In the last stanza of this poem, Elizabeth uses some repetitions in several lines to stress on the children's misery. In this stanza, she also explains that the children are cursing the English as a cruel nation because they are only concerned about its industries.

Elizabeth repeats many lines to stress on the horrible condition of the children, how tired and sad they are. This repetition is a reminder for people that such a shameful phenomenon happens in England and she hopes they would do something to overcome it.

The children consider England as a cruel nation since this country and the rich people do not care for the poor. They even use those poor people, including the children, to gain more benefits. It is shown in line 6, Will you stand, to move the world on a child's heartIn these lines, the children are asking how long they have to endure all this pain. Moreover, the phrase "to move the world on a child's heart" indicates that for the factory or mine owners, children are more preferable than the adults. During the Industrial revolution, many factories, mills, and mines used children as workers since they could be paid with little meal or low wages.

In line 9, Elizabeth writes Our blood splashes upward, $O$ gold heaper to describe that the children are angry. The "gold heaper" refers to the factory or mine owners who use the children for their own benefit. They let the children work in a very bad condition and they ignore the risk of that bad condition. Thus, their evil deed shows who they actually are which is stated in line 10, And your purple shows your path! The word "purple" means the cruelty and arrogance of the greedy factory or mine owners.

In addition, the greed and cruelty of the rich men lead the children to hate them very much. In line 11, Elizabeth writes But the child's sob in the silence curses deeper. Through this line, Elizabeth wants to show that the children are really sad and helpless that they are crying in silence. Their hearts are crying, not the eyes which is more horrible and it is scarier than the anger of the adults. In line 12, Elizabeth writes Than the strong man in his wrath. This means that when adults are angry, they can find a way to overcome the problem which triggers the anger. However, children are not as wise as the adults in finding the way out which makes it worse for them.

In the workplaces, children were treated badly by their masters. The children were the objects of beatings, physical and verbal abuse, and so on. Their long working hours was not paid as equal as the time spent in the work places. These horrible conditions resulted in the ruination of the physical and mental condition of the children.

\section{CONCLUSION}

From the analysis of the poem, The Cry of the Children, it can be concluded that Elizabeth Barret Browning views child labor as a horrible thing which is against human rights and Christianity. The employment of children 
without any proper break and meals endanger the physical and mental condition of the children. She further thinks that this social phenomenon makes the life of the poor children helpless and gloomy.

In The Cry of the Children, Elizabeth portrays child labor issues vividly and full of emotion. The use of images, such as metaphors and simile, help the readers imagine how dreadful the condition of the children is. The choice of diction in this poem also gives a proof that the children are exploited by the factory or mine owners, such as mines, wheels, round and round, and so on.

In addition, the portrayal of child labor in The Cry of the Children represents child labor issues during the Industrial Revolution. Elizabeth writes some lines to show how bad the treatment of the masters was, how tired the children are, and that this phenomenon became a social problem and political issue at that time. Even though some laws were issued by the English government, but the lower class children still suffered from the long working hours.

\section{BIBLIOGRAPHY}

Cole, G.D.H. 1966. A Short History of the British Working-Class Movement. Great Britain: Taylor Garnett Evans\&Co, Ltd.

Plumb, J.H. 1959. England in the Eighteen Century 1714-1815. Great Britain: Penguin Books.

http://www.hiddenlives.org.uk/articles/poverty.html (March 15, 2011)

http://courses.wcupa.edu/fletcher/britlitweb/ecum mingsa.htm (September 14, 2011)

http://www.ehow.com/list_7582952_child-workingconditions-industrial revolution.html ( December 6, 2011)

http://eh.net/encyclopedia/article/tuttle.labor.child britain ( December 6, 2011)

http://yale.edu/ynhti/curriculum/units/1981/2/81. 02.06.x.html (January 14, 2012) 